Dr. sc. Semir HADŽIMUSIĆ

JU Zavod za zaštitu i korištenje kulturno-historijskog

i prirodnog naslijeđa Tuzlanskog Kantona

Email: hadzi.semir@gmail.com

Stručni rad/Professional article

UDK/UDC: 94:37(497.6)"1918/1929" Selimović S. (049.3)

DOI: https://doi.org/10.52259/historijskipogledi.2021.4.6.359

\title{
Sead Selimović, ZA JEDINSTVO DOMOVINE I SLAVU DINASTIJE: Školstvo u Bosni i Hercegovini za vrijeme Kraljevine Srba, Hrvata i Slovenaca, Centar za istraživanje moderne i savremene historije Tuzla, Tuzla 2021, 442 str.
}

Bosanskohercegovačka historiografija nedavno je obogaćena važnom historijskom sintezom koja je rezultat višegodišnjeg naučnoistraživačkog rada autora, prof. dr. Seada Selimovića.

Prošlost Bosne i Hercegovine između dva svjetska rata nedovoljno je istražena. Postoji više uzroka tome, počevši od nedostatka historijskih izvora prvog reda, nedostupnosti istih ili nedostatka hrabrosti da se uđe na nesiguran teren istraživanja tema iz (ne)poželjnih političkih sistema određenog historijskog perioda.

Ono što je odmah vidljivo na osnovu jezgrovitog sadržaja, bogatog popisa izvora i literature, ali i podložnih napomena jeste da je autor uspješno savladao sve peripetije istraživačkog procesa te je mogao objektivno sagledati ulogu i značaj školstva u kontekstu društveno-političkih okolnosti koje su vladale u Kraljevini Srba, Hrvata i Slovenaca, odnosno u periodu 1918-1929. godine.

Nakon predgovora i uvoda (Osvrt na izvore i literaturu), autor izlaganje sistematizira i uokviruje u tri osnovna poglavlja:

- I. OD TRADICIJE DO MODERNIZACIJE: Školstvo u Bosni i Hercegovini za vrijeme osmanske i austrougarske uprave /25-73/,

- II. OSNOVNE ŠKOLE U SLUŽBI DRŽAVNOG JEDINSTVA I VELIČANJA DINASTIJE (1918-1929) /75-190/,

- III. SREDNJOŠKOLSKO OBRAZOVANJE U SLUŽBI DRŽAVNOG JEDINSTVA I VELIČANJA DINASTIJE (1918-1929) /191-340/

U prvom poglavlju autor istražuje i objašnjava bremenito naslijeđe prošlosti kada je u pitanju razvoj obrazovnog sistema u Bosni i Hercegovini tokom osmanske i austrougarske uprave. Naime, školstvo je tokom osmanske uprave bilo organizovano na konfesionalnoj osnovi (islamsko, pravoslavno, katoličko i jevrejsko), te se paralelno razvijalno jedno uz drugo. Prof. Selimović 
ističe da je i pored svih nastojanja i reformi koje su išle ka otvaranju državnih škola zadržano stanje u kojem su dominantnu ulogu imale konfesionalne škole.

Započeti izlazak iz uskih tradicionalnih okvira i modernizacija školstva koja je podrazumjevala davanje prvenstva njegovom svjetovnom karakteru rezultat je reformi u periodu austrougarske uprave Bosnom i Hercegovinom.

Autor analizirajući ovu problematiku predstavlja primjere $s$ terena, te vrši komparacije državnokonfesionalno, u pogledu osnovnih, ali i srednjih škola u tom periodu razvoja školstva Bosne i Hercegovine.

U drugom poglavlju profesor Selimović povezuje zahtjeve jednog sistema (Kraljevina Srba, Hrvata i Slovenaca) političke, ideološke i vjerske naravi, te analizira njihov utjecaj na osnovnoškolsko obrazovanje i razvoj istog na području Bosne i Hercegovine. Također, autor obrazlaže potrebe obrazovnog sistema naspram vlasti i tako $\mathrm{u}$ uzročno-posljedičnu vezu dovodi sve činioce historijskog procesa u kojem je rastao jedan od stubova napretka modernog
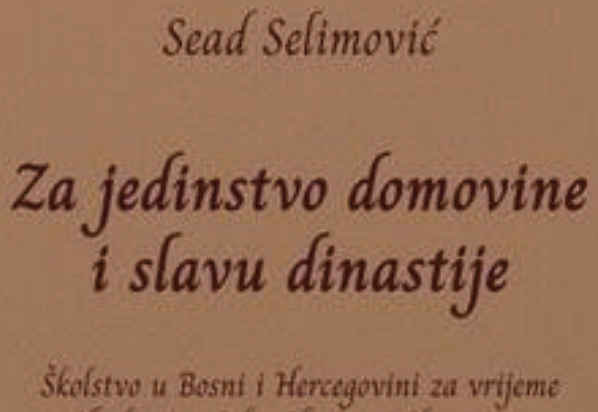
Krafjevine Srba, Frwata i Slovenaca

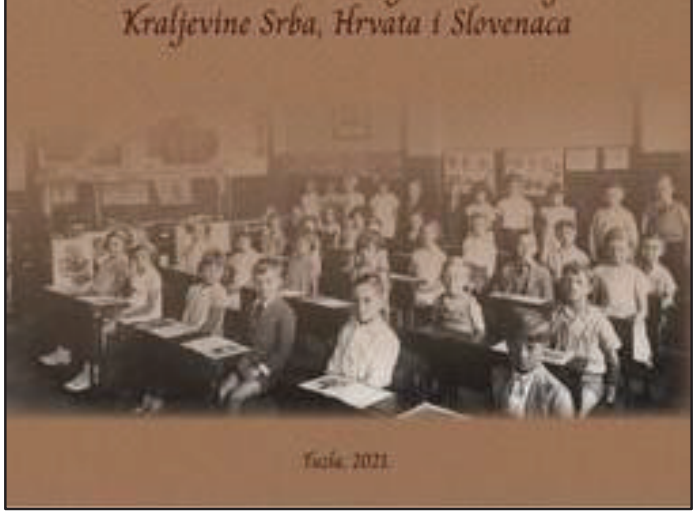
društva. Dakako, na stranicama ovog poglavlja fokus je stavljen na državne osnovne škole, ukazujući na načine u kojem su one imale poslužiti kao poluga vlasti u cilju razvijanja državne svijesti u duhu narodnog jedinstva.

Autor govori o svim karakteristikama obrazovnog sistema, o mreži osnovnih škola u Bosni i Hercegovini, opismenjavanju stanovništva, stanju školskih zgrada, nedostatku učitelja, nastavnih sredstava i pomagala, radu školskih odbora, finansiranju osnovnih škola i drugo. Profesor Selimović navodi da je u periodu 1919-1929. godine u Bosni i Hercegovini otvoreno 228 novih osnovnih škola, ali je ona i dalje zaostajala za drugim dijelovima Kraljevine SHS.

Akcenat stavlja na nastavne planove i programe, učitelje i udžbenike, sve u kontekstu ideje "narodnog i državnog jedinstva", odnosno provođenju politike vladajućeg režima. Autor ističe da su nastavnici osnovnih i srednjih škola morali odgovarati "duhu vremena" i raditi u društvenim organizacijama, ali da je bilo i onih koji to nisu željeli. To su koristili moćnici u institucijama vlasti da motive 
političke prirode potvore pod praktične i na dokazani način se prema tim nastavnicima ophode.

Svi učenici su "Srbi, Hrvati i Slovenci", naslov je kojim autor sasvim utemeljeno želi skrenuti pažnju čitalaca na još jedan od načina na koji je provođena unitaristička državna politika u kojoj je bilo mjesto samo za ideju o jednom narodu "sa tri plemena". Naime, radi se o tome da su vlasti nastojale kroz zvanične izvještaje o narodnosti učenika prikazati stanje u skladu sa svojim željama, ali i nazivu države. Tako se moglo vidjeti da su predstavljeni učenici iz reda svih jugoslavenskih naroda kao "Srbi, Hrvati i Slovenci" (jedan narod), a da se kao posebna kategorija uopće ne pominju učenici ostalih naroda (Makedonci, Bošnjaci, Crnogorci, Albanci), koji su također bivali svrstani u kategoriju "Srbi, Hrvati i Slovenci”, zaključuje Selimović.

U ovom periodu vršeno je ujednačavanje nastavnih planova i programa, a izvršene su korekture u grupi nacionalnih predmeta (historija, geografija, srpski ili hrvatski jezik) tako što je fokus stavljen na historiju i geografiju Srba, Hrvata i Slovenaca, a za školsku lektiru propisana su djela iz srpske, hrvatske ili slovenačke književnosti. "Sve ono što je u nastavnim planovima i programima isticalo i veličalo Habzburšku dinastiju, zamijenjeno je veličanjem i odanošću dinastiji Karađorđevića", navodi autor.

Još jedan od ključnih faktora za ideološko-političko oblikovanje obrazovnog sistema jesu udžebnici, te autor apostrofira da su vlasti upravo kroz udžbenike nastojale da provode školsku politiku koja je u skladu s državnom politikom. S tim u vezi, ukazano je i na naredbu od 15. novembra 1928, upućenu svim direktorima i upraviteljima škola, u kojoj je "zaprijećeno ličnom odgovornošću upravitelja", ukoliko se prilikom pregleda škola ustanovi da se koriste neodobrene knjige (udžbenici).

$\mathrm{Na}$ kraju poglavlja o osnovnim školama, koristeći se isključivo historijskim izvorima prvog reda, autor objašnjava stanje u pogledu djelovanja konfesionalnih osnovnih škola s posebnim osvrtom na islamske i katoličke osnovne škole, dok su kako ističe pravoslavne osnovne škole početkom Prvog svjetskog rata bile zatvorene, a nakon rata pretvorene u državne. Također, prof. Selimović piše o položaju 29 škola nacionalnih manjina, koliko ih je bilo u Bosni i Hercegovini nakon završetka Prvog svjetskog rata kada su se našle "na udaru države".

Srednjoškolsko obrazovanje u službi državnog jedinstva i veličanja dinastije (1918-1929) naziv je najobimnijeg poglavlja ove knjige, a koje je također podijeljeno na dvije osnovne cijeline: Državne srednje škole i Konfesionalne srednje škole.

O diobi nadležnosti u srednjoškolskom obrazovanju između ministarstva prosvjete u Beogradu i Pokrajinske uprave za Bosnu i Hercegovinu, prof. Selimović govori na početku ovog poglavlja navodeći konkretne primjere provođenja nadležnosti u praksi. "Tako je upravu srednjih škola imenovalo Ministarstvo Prosvjete Kraljevine SHS, dok je privremenu upravu u odsutnosti direktora postavljala Pokrajinska uprava za Bosnu i Hercegovinu. Odsustva 
nastavnika do tri mjeseca odobravala je Pokrajinska uprava, a više od toga Ministarstvo", dok je ministar prosvjete 24. januara 1925. godine naredio da se definitivno likvidiraju prosvjetna odjeljenja u Zagrebu, Ljubljani i Sarajevu, ističe Selimović.

Proces ujednačavanja nastavnih planova i programa, te organizacije srednjih škola na nivou Kraljevine SHS tekao je sporo. Autor navodi da su ova pitanja nešto intenzivnije pokrenuta školske 1925/1926. godine kada je postavljeno pitanje centralizirane personalne službe. Organizacija školske godine, disciplinski propisi, način održavanja ispita. bila su pitanja koja je Ministarstvo prosvjete postepeno preuzimalo u svoju isključivu nadležnost. Ipak, do 1929. godine u većini srednjih škola u Bosni i Hercegovini radilo se prema zatečenim nastavnim planovima i programima koji su se samo u neznantnoj mjeri prilagodili postojećim prilikama u zemlji.

Autor iscrpno elaborira i tabelarno predstavlja podatke o broju učenika u razredima, odjeljenjima, o vjerskoj strukturi i drugim karakteristikama nastavnog procesa u srednjim školama širom Bosne i Hercegovine. Učiteljske škole u Sarajevu, Mostaru, Derventi i Banjaluci, te gimnazije u Sarajevu Mostaru, Banjaluci, Tuzli, Bihaću, Bijeljini, Derventi, Livnu, Prijedoru, Trebinju, Brčkom, Bosanskoj Gradišci, Foči, Gacku i Stocu predmet su istraživanja na stranicama ove publikacije.

Svoje nezadovoljstvo nastavnim programima srednjih škola iskazivali su i građani pojedinih područja Bosne i Hercegovine. U tome su se posebno istakli građani Tuzle, Travnika i Mostara koji su umjesto novoformiranih građanskih škola tražili vraćanje starih trgovačkih škola u svoje gradove. U tim zahtjevima jedino su uspjeli građani Tuzle, u kojoj je 1927. godine otvorena Dvorazredna trgovačka škola.

Niže stručne škole u Bosni i Hercegovini nastavile su s radom i poslije završetka Prvog svjetskog rata. Iako su bila u kompetencijama pojedinih državnih ministarstava, pitanja organizacije i rada nižih stručnih škola rješavana su na nižim nivoima vlasti (općine, kotarevi, oblasti), što je dovelo do različitih oblika nižeg stručnog obrazovanja u Bosni i Hercegovini. Radile su muške zanatske, ženske stručne, ženske zanatske i šegrtske škole. Upravo o tome piše profesor Selimović na kraju cjeline o državnim srednjim školama.

Pored državnih srednjih škola, u Bosni i Hercegovini su u periodu 19181929. godine radile i konfesionalne srednje škole. Sve one nisu bile istog ranga i kvaliteta, ali bez obzira na to one su zauzimale značajno mjesto u školskom sistemu Bosne i Hercegovine, pojašnjava autor, navodeći primjere islamskih, katoličkih, pravoslavnih i jevrejskih škola, što je i posljednji sadržaj poglavlja o srednjoškolskom obrazovanju u Bosni i Hercegovini pod Kraljevinom SHS.

$\mathrm{Na}$ kraju knjige je zaključak na bosanskom i engleskom jeziku, pregled izvora i literature, registar ličnih imena, registar geografskih pojmova, te izvodi iz recenzija prof. dr. Adnana Velagića, prof. dr. Izeta Šabotića, prof. dr. Senaida Hadžića, kao i bilješka o autoru. 
Dosljedno primjenjujući sva pravila metodologije historijskog istraživanja, na osnovu prije svega neobjavljenih i objavljenih historijskih izvora različite provenijencije, ali i relevantne i recentne domaće i strane literature, nastala je ova historijska monografija koja oslikava jasnu historijsku sliku navedenog pitanja $\mathrm{i}$ tematike, te daje nadasve veliki doprinos historiografiji Bosne I Hercegovine.

Posebno treba istaći obim korištenih alata i značajki koje se ne viđaju često u historijskim knjigama, a koje su izražene kroz poseban način obrade i prezentacije statističkih podataka i historijskih činjenica. Naime, autor je sve značajnije elaborirane činjenice pregledno predstavio u čak 94 samostalno kreirane tabele.

Zbog svega navedenog, knjigu Za jedinstvo domovine i slavu dinastije. Školstvo u Bosni i Hercegovini za vrijeme Kraljevine Srba, Hrvata i Slovenaca, autora prof. dr. Seada Selimovića preporučujem naučnoj i široj javnosti. 